\title{
Merupa Wujud Evangelikalisme di Indonesia: Suatu Usulan Awal
}

\section{Shaping the Form of Evangelicalism in Indonesia: A Preliminary Proposal}

\author{
Adrianus Yosia \\ Wesley Theological Seminary, USA \\ Korespondensi: adrianus.yosia2305@gmail.com
}

\begin{abstract}
Abstrak: Artikel ini merupakan suatu usulan awal untuk mengejawantahkan bagaimana rupa "muka publik" dari gerakan injili di Indonesia. Artikel ini akan membahas siapakah kaum injili di Indonesia, karakteristik teologis dari kaum injili, dan wujud usulan partisipasi gerakan injili di Indonesia. Karakteristik teologis dari kaum injili yang penulis usulkan adalah modifikasi dari Quadrilateral Bebbington, yaitu Pentagram Larsen. Sebagai dampaknya, artikel ini ingin mengusulkan dua gerakan dari merupa wujud gerakan injili di Indonesia, yaitu gerakan ke dalam dan gerakan keluar. Gerakan ke dalam ini merupakan semangat gereja untuk terus mereformasi diri, sedangkan gerakan ke luar ini merupakan semangat gereja untuk mereformasi kondisi sosial. Inilah suatu usulan awal dari merupa wujud gerakan injili di Indonesia.
\end{abstract}

Kata kunci: Gerakan Injili, Kaum Injili, Evangelikalisme, Quadrilateral Bebbington, Pentagram Larsen

Abstract: This article was written as a preliminary opinion to explore the "public face" of evangelicalism as a movement in Indonesia. Furthermore, this article will discuss who are the evangelicals in Indonesia, the theological characteristics from the evangelicals, and the form of evangelical's participation in Indonesia. The writer will argue that the modification from Bebbington's Quadrilateral, Larsen's Pentagram, can be theological characteristics from the evangelicals in Indonesia. As a consequence, this article will propose two ways of movements from evangelicalism in Indonesia, which are the inward and outward movements. The inward movement is the spirit of the evangelical church to reform itself, while the outward flow is the eagerness of the evangelical church to reform the social condition. Thus, these are initial observations for shaping evangelicalism in Indonesia.

Keywords: Evangelical Movement, The Evangelicals, Evangelicalism, Bebbington's Quadrilateral, Larsen's Pentagram 


\section{PENDAHULUAN}

Bagaimanakah rupa "wajah publik" kaum injili Indonesia mendatang? Pertanyaan ini keluar di dalam benak ketika penulis sedang membaca mengenai entri Indonesia dalam World Christian Encyclopedia edisi ketiga. ${ }^{1}$ Ada dua hal yang membuat terperangah ketika membaca kamus prestisius tersebut dan membandingkannya dengan edisi kedua. ${ }^{2}$

Pertama, pembahasan mengenai bangkitnya kaum Pentakosta dan Karismatik di Indonesia yang bersandingan dengan gerakan Protestanisme dan juga Katolik di Indonesia. Perihal ini menarik mengingat gerakan Pentakosta dan karismatik dibahas di dalam bagian dari gerakan Protestanisme pada edisi kedua. ${ }^{3}$ Kedua, hal yang membuat penulis bertanya-tanya adalah hilangnya pembahasan mengenai pergerakan kaum injili dalam artikel tersebut. Padahal, pada edisi kedua, terdapat pembahasan mengenai "satu organisasi ekumenis yang lebih kecil" yang bernama Dewan Gereja-gereja Injil di Indonesia. Penulis menduga bahwa organisasi yang disebut pada dokumen tersebut adalah PII dengan mengingat bahwa waktu pembentukan yang hampir sama dengan penjelasan tersebut. ${ }^{4}$ Namun, andaikan organisasi

${ }^{1}$ Todd M Johnson dkk., World Christian Encyclopedia, 3 ed. (Edinburgh: Edinburgh University Press, 2020), 395-397.

${ }^{2}$ Kamus World Christian Encyclopedia diciptakan oleh seorang misionaris yang bernama David Barrett. Tujuan Barrett menciptakan kamus ini adalah suatu pendataan mengenai keadaan kekristenan dunia. Tidak hanya itu, data-data yang ada pada kamus itu pun ditujukan sebagai alat yang membantu penginjilan dunia. Pada edisi yang ketiga, Todd Johnson dan Gina A. Zurlo menyatakan bahwa tujuan dari kamus ini adalah pendataan secara kuantitatif dari kekristenan dunia saat ini. Penulis mendapatkan respons ini ketika menghadiri konferensi peluncuran kamus ini pada Berkley Center for Religion, Peace and World Affairs dari Georgetown Uni-versity pada 21 Februari 2020.

${ }^{3}$ David B. Barrett, George Thomas Kurian, dan Todd M. Johnson, ed., World Christian Encyclopedia, ed. ke-2 (Oxford: Oxford Univsity Press, 2001), 375.

${ }^{4}$ Ibid., 376. Penulis menduga bahwa organisasi ini adalah PII (Persekutuan Injili Indonesia) atau yang dikenal dengan nama PGLII pada saat ini. Melihat kedekat- tersebut bukanlah PII, tetap saja hal ini tidak mengubah argu-men penulis yang akan mencoba mengelabo-rasi pengamatannya ini.

Mengaitkan kedua data ini dengan pertanyaan pada awal tulisan ini, apakah meningkatnya kaum Pentakosta di Indonesia dapat menjadi "wajah" dari kaum injili? Rasanya jawaban "ya" merupakan jawaban yang sulit untuk mendapatkan legitimasi dari kaum injili sendiri. Jan S. Aritonang menyatakan bahwa ada sebagian gereja Pentakosta yang mengklaim bahwa mereka beridentitas injili, namun sebagian teolog injili sendiri tidak mengakui hal tersebut. ${ }^{5}$ Sebagaimana yang sudah diutarakan pula pada data kedua, baik organisasi "Dewan Gereja-gereja Injil Indonesia" adalah PII ataupun bukan, ternyata kamus tersebut tidak mengenal gerakan injili di Indonesia, walaupun pada bagian awal dari kamus itu, mereka mendefinisikan gerakan injili (setidaknya pada edisi kedua). Dengan demikian, bagaimanakah "wajah" dari kaum injili di Indonesia, mengingat bahwa Aritonang pun mendefinisikan kaum injili di Indonesia sebagai "arus ketiga."

Tentunya, apa yang dimaksudkan dengan "wajah publik" dari kaum injili ini dapat dimaknai dengan beragam cara. Gerith Singgih, mengutip pemikiran Alwi Shihab, pernah menyatakan bahwa "kaum evangelikal keberatan dengan dialog, sedangkan kaum oikumenikal setuju dengan dialog."7 Di dalam konteks ruang publik Indonesia yang multi-agama, dialog yang dimaksud Singgih

an waktu pembentukan organisasi ini dengan PII (pada tahun 1971), sepertinya dugaan ini dapat diverifikasi (lih. "Sejarah Singkat Persekutuan Injili Indonesia," diakses 28 April 2020, https://www.pglii.or.id/profil/sejarah/).

${ }^{5}$ Jan S. Aritonang dan Karel Steenbrink, A History of Christianity in Indonesia, Studies in Christian Mission (Leiden, Boston: Brill, 2008), 868.

${ }^{6}$ Aritonang dan Steenbrink, A History of Christianity in Indonesia.

${ }^{7}$ Gerith Singgih, "Tema Kerukunan Umat Beragama di dalam Diskusi Pakar Agama," dalam Agama dalam Dialog, ed. Balitbang PGI (Jakarta: Gunung Mulia, 1999), 39. 
tentunya berhubungan dengan keterlibatan kaum injili di dalam ruang publik. ${ }^{8}$ Namun, beberapa waktu terakhir ini, kaum injili sendiri sudah mulai memperhatikan isu-isu yang berhubungan dengan dialog antaragama, ${ }^{9}$ dan juga kemiskinan, ${ }^{10}$ ekologi, ${ }^{11}$ ataupun politik $^{12}$ di dalam bidang kajian akademis. Tergantung bagaimana pemaknaan terhadap kata publik, kaum injili pun tentunya telah melakukan berbagai aktivitas dalam ruang publik via organisasi-organisasi injili. Apa yang peulis ingin bahas bukanlah "wajah publik" di dalam konteks ini, walaupun halhal ini pun akan beririsan dalam tulisan ini. Dengan melihat data-data dari World Christian Encyclopedia, apa yang ingin dilakukan oleh tulisan ini adalah mencoba mengusulkan suatu "wajah publik" dalam arti kaum injili sebagai suatu kegerakan (movement) dengan identitas tertentu dan dapat dilihat berdasarkan karya-karya nyata di ruang publik Indonesia. Dengan demikian, walaupun gerakan injili ini terkesan tidak "tampak," tetap saja gerakan ini ada.

Tesis dari tulisan ini adalah wujud dari gerakan injili (evangelicalism) di masa depan

${ }^{8}$ Pada artikel tersebut, sebenarnya tidak jelas siapa atau apakah kelompok "evangelikal" ini. Namun, dengan melihat sejarah munculnya organisasi injili-ekumenis pada paruh abad ke-20, kemungkinan besar kata injili yang dimaksud di sini sejalan dengan istilah injili yang akan saya bahas pada artikel ini.

${ }^{9}$ Adrianus Yosia, “Apakah yang Cape Town Perlu Katakan pada [Kaum Injili di] Indonesia?: Suatu Tinjauan dan Refleksi Terhadap Komitmen Cape Town dan Implikasinya pada Kaum Injili di Indonesia," Veritas: Jurnal Teologi dan Pelayanan 16, no. 2 (Desember 2017): 115-134, https://doi.org/10.36421/veritas.v16i2.13.

${ }^{10}$ Ferry Y. Mamahit, "Globalisasi, Gereja Injili dan Transformasi Sosial," Veritas: Jurnal Teologi dan Pelayanan 6, no. 2 (Oktober 2005): 253-375, https://doi.org/10.36 421/veritas.v6i2.151.

${ }^{11}$ Yohanes Hasiholan Tampubolon, "Refleksi Kepedulian Injili Pada Isu Lingkungan Hidup," Stulos 18, no. 1 (Januari 2020): 53-76; Ferry Y. Mamahit, "Apa Hubungan Porong dengan Yerusalem?: Menggagas Suatu Ekoteologi Kristen," Veritas: Jurnal Teologi dan Pelayanan 8, no. 1 (April 2007): 1-24, https://doi.org/10.36421/ veritas.v8i1.174.

${ }^{12}$ Togardo Siburian, "Teologi Kenabian Injili untuk Politis," Stulos 18, no. 1 (Januari 2020): 26-52. adalah suatu gerakan ekumenisme yang sifatnya lintas denominasi dan organisasi. ${ }^{13}$ Lewat tulisan ini, penulis ingin mengusulkan suatu wujud kaum injili di masa mendatang. Tentunya, usulan ini merupakan suatu investigasi awal. Dengan demikian, untuk mencapai hal ini, tulisan ini akan dibagi ke dalam tiga bagian besar.

Pertama-tama, penulis akan mencoba memetakan kaum injili di Indonesia yang biasanya didefinisikan secara organisasional, setelah itu penulis akan mendedah karakteristik teologis kaum injili dan mengusulkan pembacaan yang lebih luas dengan memodifikasi konsep Quadilateral Bebbington, dan terakhir memikirkan kembali peranan kaum injili di dalam ruang publik Indonesia yang bersesuaian dengan bagian kedua tersebut. Lewat investigasi awal ini, penulis hendak mengusulkan bahwa gerakan injili di Indonesia sejatinya adalah suatu gerakan lintas organisasi dan juga lintas denominasi.

\section{WUJUD EVANGELIKALISME DI INDONESIA: SUATU ORGANISASI?}

Penulis memulai refleksi ini dengan memikirkan kembali wujud fisik dari gerakan injili di Indonesia. Penulis melihat gerakan injili di Indonesia masih terpaku dan terkait dengan suatu organisasi tertentu sebagai wujud fisik dari komunitas injili. Dengan cara pandang ini, komunitas injili dan gerakan injili di Indonesia hanya dibatasi pada organisasi dan juga kegerakan yang dilakukan oleh organisasi-organisasi tersebut. Di Indonesia sendiri, organisasi payung dari kaum injili adalah Persekutuan Gereja-gereja dan Lembaga-lembaga Injili di Indonesia (PGLII)

\footnotetext{
${ }^{13}$ Kata evangelikalisme ini diserap dari kata evangelicalism. Kata ini memang sangat abstrak, namun penulis akan menggunakan kata ini dengan suatu ide yang menunjukkan identitas dari kaum injili. Tidak hanya itu, berbicara mengenai evangelikalisme berarti berbicara mengenai pergerakan dari kaum injili. Penulis juga akan memaknai kata ini untuk mencakup identitas dari kaum injili yang ditunjukkan oleh tindakannya pada ruang publik.
} 
yang berafiliasi dengan WEA di dalam konteks gereja atau pun Persekutuan Mahasiswa Teologi Injili Indonesia (Permasti) di dalam konteks pendidikan tinggi. ${ }^{14}$ Baik PGLII atau Permasti memang merupakan poros berteologi dari kaum injili di Indonesia dan di dalam organisasi-organisasi inilah sejatinya kaum injili dapat "dikenal" secara konkret. Namun, apabila wujud fisik dari kaum injili di Indonesia ini hanya dikaitkan dengan dua organisasi tersebut, penulis melihat ada empat masalah yang dapat muncul.

Pertama, adanya pemakaian kata injili di dalam nama organisasi-organisasi lintas denominasi dan organisasi di Indonesia sebagaimana yang diutarakan oleh Aritonang,

di antara sekitar 400 organisasi gereja non-Katolik di Indonesia, ditambah dengan 400-an yayasan, paling kurang setengah jikalau bukan semua, mengaku sebagai gereja dan yayasan yang injili. Di dalamnya termasuklah sejumlah gereja yang masuk kategori arus utama (misalnya GMIM, GMIT, GMIH, GMIST, GKI Papua, dsb.)—di mana huruf I merupakan singkatan dari "Injili"-dan juga sebagian besar gereja Pentakosta. ${ }^{15}$

Walaupun gereja arus utama dan juga gereja Pentakosta yang disebutkan di atas secara organisasional tidak termasuk di dalam PGLII, Aritonang menambahkan bahwa setiap gereja tersebut menyatakan dirinya injili. Terlepas dari makna injili yang dipahami oleh organisasi tersebut, problem pertama ini menyatakan bahwa ada gereja-gereja yang tidak tergabung di dalam organisasi injili namun mengaku dirinya injili.

\footnotetext{
${ }^{14}$ World Evangelical Alliance adalah organisasi injili yang dibentuk pada tahun 1951 di Inggris sebagai organisasi injili lintas negara (lih. "Who We Are?," https:// worldea.org/en/who-we-are). Organisasi ini pun bekerja sama dengan gerakan injili terbesar abad ini, yaitu gerakan Lausanne.

${ }^{15}$ Jan S. Aritonang, Berbagai Aliran di Dalam dan di Sekitar Gereja, Revisi. (Jakarta: Gunung Mulia, 2016), 282-283.
}

Kedua, keanggotaan ganda ataupun lebih pada organisasi-organisasi payung di Indonesia. Di Indonesia terdapat tiga lembaga sebagai organisasi payung yang mewakili tiga arus utama dari Protestan, yaitu PGI (Persekutuan Gereja-gereja di Indonesia, ekumenis), PGPI (Persekutuan Gereja-gereja Pentakosta di Indonesia, Pentakosta), dan PGLII. Namun, ada fenomena yang menarik di mana sebuah gereja dapat masuk ke dalam lebih dari satu organisasi ataupun seakan-akan "keluar" dari organisasi yang seasas dengannya. Misalkan saja, Aritonang mengamati bahwa beberapa gereja merupakan bentukan yayasan injili di Indonesia justru memilih organisasi ekumenis sebagai payung organisasinya. ${ }^{16}$ Binsar Pakpahan juga mengamati bahwa ada gereja yang bernaung di bawah dua ataupun tiga organisasi tersebut. ${ }^{17}$ Tidak terlalu jelas mengapa ada gereja-gereja yang melakukan hal tersebut, namun terlihat betapa rapuhnya klaim bahwa organisasi injili saja yang dapat menjadi wadah bagi gerakan injili di Indonesia, mengingat ada juga organisasi lain yang dapat menampung organisasi injili ini.

Ketiga, semakin konvergennya butir-butir teologis dalam dokumen kaum ekumenis maupun injili di dunia. Di dalam sejarah pembentukan organisasi-organisasi injili di Indonesia ataupun Amerika, ada semangat kontra Injil sosial dan liberalisme (yang diwakili oleh ekumenisme pada zamannya) sebagai latar belakangnya. Misalkan saja, gerakan Lausanne dapat dipandang sebagai suatu respons terhadap konsep Injil Sosial yang dikumandangkan oleh WCC (World Council of Churches), majalah Christianity Today merupakan tandingan ide teologis dari majalah Christian Century, dan bahkan pembentukan PGLII sebagai kontra PGI pun tidak dapat dilepaskan dari konteks

${ }^{16}$ Aritonang dan Steenbrink, $A$ History of Christianity in Indonesia.

${ }^{17}$ Binsar Pakpahan, "Daftar Anggota Gereja PGI, PGPI, PGLII," binsarspeaks.net, last modified 2013, diakses Juni 30, 2018, http://binsarspeaks.net/?p=1983. 
kontra Injil sosial dan juga liberalisme ini. ${ }^{18}$ Namun, penulis mengamati-bersama dengan Økland-bahwa dokumen-dokumen ekumenis menjadi semakin "injili" dan dokumen-dokumen dari organisasi injili menjadi semakin ekumenis di dalam beberapa waktu terakhir. ${ }^{19} \varnothing$ kland mengamati bahwa konvergensi ini dapat terjadi karena ada anggota ekumenis yang tergabung dalam golongan injili dan demikian sebaliknya. Bahkan Emilio Castro pun mengamati bahwa di dalam konsep misi Allah, kaum ekumenis dan juga injili sudah semakin mempunyai "satu suara" di dalamnya. ${ }^{20}$ Tentu PGI yang mengikuti arus ekumenis (WCC) dan PGLII yang mengikuti arus injili (gerakan Lausanne dan WEA-World Evangelical Alliance) ini pun mempunyai kecenderungan yang sama. Tentu, penulis sadar bahwa "kesamaan" ini bukan berarti tiada membawa masalah sebagaimana yang David Hesselgrave utarakan. ${ }^{21}$ Hanya saja, apa yang penulis soroti adalah mulai adanya kesamaan antara kubu ekumenis dan juga injili. Dengan demikian, tidak tertutup kemungkinan bahwa peleburan ide ini pun sejatinya terjadi juga di Indonesia.

Sehubungan dengan poin ketiga ini, hadirnya khotbah-khotbah yang dapat diakses via Youtube, Facebook ataupun media sosial lainnya bisa jadi membuat batasan ini menjadi kabur juga. Bisa saja ada orang-orang yang bergereja di dalam gereja yang tidak tergabung di dalam organisasi injili namun gemar mendengarkan khotbah-khotbah dari gereja-gereja injili. Walaupun bisa saja peri-

\footnotetext{
${ }^{18}$ Lih. "Sejarah Singkat Persekutuan Injili Indonesia."

${ }^{19} \emptyset$ yvind Økland, "Dialogue and Mission in a Globalized World Developments in the World Council of Churches and the Lausanne Movement," dalam The Lausanne Movement: A Range of Perspectives, Regnum Edinburgh Centenary Series 22 (Oxford: Regnum Books International, 2014), 367-382.

${ }^{20}$ Emilio Castro, "Ecumenism and Evangelicalism: Where Are We?," The Ecumenical Review 70, no. 1 (Maret 2018): 54-62.

${ }^{21}$ David J. Hesselgrave, "Did Cape Town 2010 correct the 'Edinburgh Error'?: A preliminary analysis," Southwestern Journal of Theology 55, no. 1 (2012): 77-89.
}

hal sebaliknya yang terjadi, namun poin yang ingin ditekankan adalah bahwa pemikiran yang "injili" ini ternyata juga didapati via khotbah di luar gereja injili. Dengan demikian, terlihat ada konvergensi ide yang lebih luas lagi di dalam kalangan akar rumput sehingga seharusnya ada kaum injili yang berada di luar organisasi injili.

Terakhir, terdapat organisasi parachurch yang bekerja lintas denominasi di kampuskampus di Indonesia. Simon Chan mengamati bahwa salah satu penyebab meleburnya orang-orang injili di dalam organisasi noninjili di Asia dikarenakan pergerakan organisasi-organisasi parachurch seperti Campus Crusade, InterVarsity Christian Fellowship, ataupun Navigator. ${ }^{22}$ Penulis melihat bahwa argumen Chan sangat tepat untuk melihat kegerakan yang sama di Indonesia. Organisasi-organisasi seperti LPMI (yang berafilisasi dengan Campus Crusade), Perkantas (yang berafiliasi dengan InterVarsity Christian Fellowship), atau Navigator pun sudah melakukan pemuridan dan juga menjaring banyak kaum muda lintas denominasi di Indonesia. Walaupun tidak semua kampus di Indonesia sudah terjangkau oleh lembaga-lembaga ini, penulis melihat bahwa ada potensi yang cukup besar dari lembaga parachurch ini. Dengan demikian, terdapat kemungkinan bahwa ada orang-orang yang "injili" namun berada di luar organisasi gereja injili.

Lewat empat perihal ini, penulis ingin menyatakan bahwa komunitas injili yang ada di Indonesia ini seharusnya "lebih besar" daripada komunitas injili yang terdaftar dan juga terlihat di dalam organisasi injili. Tentu, empat pengamatan ini merupakan suatu analisis awal dan mungkin perlu penjabaran secara lebih mendalam. Namun, klaim yang ingin penulis utarakan adalah bahwa ada ko-

\footnotetext{
${ }^{22}$ Simon Chan, "Evangelical Theology in Asian Context," dalam The Cambridge Companion to Evangelical Theology, ed. Daniel J. Treier dan Timothy Larsen (Cambridge: Cambridge University Press, 2007), 226.
} 
munitas injili yang berada di dalam gereja arus utama ataupun gereja Pentakosta dan Karismatik di Indonesia yang biasanya tidak "dicap" injili secara organisasional oleh orang injili sendiri. Tidak hanya itu, orangorang yang mempunyai pemikiran injili pun dapat berada di luar organisasi gereja injili ini, termasuk di dalam organisasi parachurch dan mungkin tidak terafiliasi dengan organisasi injili itu sendiri. Dengan demikian, bagaimanakah wujud gerakan injili yang ada di Indonesia ini dan dapat menampung keadaan yang sudah diutarakan di atas? Terlebih lagi, bagaimanakah wujud gerakan injili di Indonesia, di tengah-tengah berkembangnya gerakan Pentakosta di Indonesia? Penulis mengusulkan wujud fisik dari gerakan injili di Indonesia ini berupa suatu gerakan inklusif (movement) antarorganisasi dan antardenominasi.

David Clark mengusulkan untuk melihat evangelikalisme sebagai suatu gerakan (movement) spiritual dan juga eksperiensial (experiential). Clark menyatakan demikian:

Evangelikalisme adalah suatu gerakan dari manusia dan juga komunitas-komunitas yang bergerak menuju Allah Bapa, oleh Roh Kudus, melalui penebusan Kristus. Di dalam perjalanan menuju Bapa inilah, kita merasakan kesembuhan secara spiritual dan kepenuhan yang dinyatakan di dalam kehidupan ibadah dan pelayanan. $^{23}$

Lewat usul dari Clark, pengalaman spiritual dan eksperiensial inilah yang menjadi motor bagi kaum injili untuk "bergerak." Karena pengalaman dan juga penguatan secara spiritual inilah gerakan injili ini memfokuskan diri kepada "agama sejati sebagai perlawanan terhadap afiliasi nominal kemapanan gereja dan agama hukum dan tradisi." ${ }^{24}$ De-

${ }^{23}$ David K. Clark, To Know and Love God: Method for Theology, Foundations of Evangelical Theology (Illinois: Crossway, 2003), loc. 467, kindle. ngan melihat ide-ide ini, maka penulis dapat menyatakan bahwa gerakan injili ini sejatinya bersifat interdenominasi dan juga interorganisasi. Namun, mendefinisikan kegerakan injili sebagai suatu gerakan masih belum memberikan suatu karakteristik dari gerakan ini, mengingat ada begitu banyak gerakan spiritual dan juga pengalaman agamis di duania ini. Dengan demikian, sebagai pelengkap pembahasan dari kegerakan ini, penulis akan membahas karakteristik dari gerakan ini.

\section{MENDEDAH KARAKTERISTIK TEOLOGIS DARI EVANGELIKALISME INDONESIA}

Perdebatan untuk mendefinisikan teologi injili yang ditinjau dari sisi sejarah, sosial, biblika, ataupun teologis sangatlah rumit. ${ }^{25}$ Terlebih lagi, kesejarahan dari kaum injili di Indonesia pun terkait erat dengan sejarah dari kaum injili di Amerika Utara. ${ }^{26}$ Tanpa berusaha untuk terlalu menyederhanakan problem ini, secara umum karakteristik yang didefinisikan oleh David Bebbington sudah cukup untuk mendefinisikan karakteristik dari kaum injili. ${ }^{27}$ Menurut Bebbington,

\footnotetext{
${ }^{24}$ Bruce Hindmarsh, "What Is Evangelicalism?," Christianity Today, Maret 2018, diakses 1 Juli 2018, https://www.christianitytoday.com/ct/2018/march-webonly/what-is-evangelicalism.html.

${ }^{25}$ Kevin J. Vanhoozer dan Daniel J. Treier, Theology and the Mirror of Scripture: A Mere Evangelical Account, Studies in Chrisian Doctrine and Scripture (Downers Grove, London: InterVarsity, Apollos, 2016), 19.

${ }^{26}$ Aritonang dan Steenbrink, A History of Christianity in Indonesia, 869-879.

${ }^{27}$ Timothy Larsen, "Defining and Locating Evangelicalism," dalam The Cambridge Companion to Evangelical Theology, ed. Timothy Larsen dan Daniel J. Treier (Cambridge: Cambridge, 2007), 1; John Stott, Evangelical Truth: A Personal Plea for Unity, Integrity and Faithfulness (Cumbria: Langham Global Library, 2013), 10. Untuk perdebatan model ini di Indonesia sendiri, lih. Chandra Wim, "The Chronicles of Evangelicalism: Sebuah Pengantar Historis Terhadap Gerakan Evangelikal," Veritas: Jurnal Teologi dan Pelayanan 12, no. 2 (Oktober 2011): 185207, https://doi.org/10.36421/veritas.v12i2.249; bdk. Thio Christian Sulistio, "Identitas Kaum Injili dan Perannya dalam Memperkembangkan Teologi," Stulos 18, no. 1 (Januari 2020): 1-25.
} 
kaum injili mempunyai empat karakteristik yaitu, conversionism, activism, biblicism, dan cruci-centrism. Empat karakteristik ini biasanya disebut sebagai Quadrilateral Bebbington.

Conversionism berarti suatu pandangan bahwa kehidupan seorang manusia perlu diperbaharui. Kaum injili menekankan adanya suatu perubahan hidup dari keberdosaan menuju kepada kehidupan yang baru di dalam Kristus. Biblicism berarti bahwa kaum injili menekankan Alkitab sebagai otoritas utama. Activism berarti suatu pandangan bahwa injil perlu diekspresikan di dalam segala bidang kehidupan. Inti dari karakteristik ini adalah penyebaran berita kepada "dunia" oleh orang-orang yang sudah mengalami perubahan hidup di dalam Kristus. Cruci-centrism adalah pandangan yang menekankan karya pengorbanan Kristus di kayu salib. Penekanan terhadap karya kematian Kristus di kayu salib dan kebangkitanNya merupakan jantung dari kaum injili.

Timothy Larsen mencoba melengkapi Quadrilateral Bebbington dengan menyatakan bahwa kaum injili

menekankan pekerjaan dari Roh Kudus di dalam kehidupan seseorang untuk membawa pertobatan dan juga suatu kehidupan yang terus menerus di dalam persekutuan dengan Allah dan melayani Allah dan sesama, termasuk di dalamnya kewajiban seluruh orang percaya untuk berpartisipasi di dalam tugas mengabarkan Injil kepada semua orang. ${ }^{28}$

Pentagram Larsen ini dapat menjadi karakteristik yang cukup kuat menggambarkan karakteristik teologis dari kaum injili dan dengan karakteristik ini pula kaum Karismatik dan Pentakostal pun dapat berbagian di dalam gerakan ini.
Apabila Pentagon Larsen ini mau dihubungkan dengan konsep Clark dan Hindmash mengenai evangelikalisme sebagai suatu gerakan maka akan tampak korelasinya. Evangelikalisme adalah suatu gerakan yang percaya bahwa perubahan hidup yang dimulai oleh Roh Kudus merupakan hal yang sangat penting karena perubahan kehidupan ini adalah tanda bahwa seseorang sudah mengalami kesembuhan dan kepenuhan spiritual di dalam-Nya (conversionism). Gerakan ini juga ingin menyatakan suatu undangan pada orang lain untuk merasakan kepenuhan dan kesembuhan spiritual yang sama. Evangelikalisme adalah suatu gerakan yang percaya bahwa Alkitab adalah otoritas tertinggi di dalam kehidupannya, sehingga di dalam tuntunan Roh Kudus, kaum injili dapat melihat seluruh aspek kehidupan di dalam terang kebenaran ini (biblicism dan activism). Evangelikalisme adalah suatu kegerakan yang mengakui karya keselamatan dari Yesus Kristus sebagai pusat pengajarannya, sehingga Kristus adalah satu-satunya Juruselamat, teladan kehidupan, seseorang yang dipenuhi dan dikuasai Roh Kudus di dalam inkarnasiNya, dan juga gerakan ini percaya akan supremasi Kristus akan seluruh kuasa-kuasa dunia ini (cruci-centrisme). Tidak hanya itu, gerakan ini juga ingin menyatakan kabar baik mengenai Yesus Kristus di dalam tuntunan Roh Kudus pada dunia.

Lantas, bagaimanakah karakteristik ini dapat cocok dengan orang-orang yang ada di luar organisasi injili seperti gereja arus utama? Sebagaimana pengamatan yang sudah diutarakan pada bagian sebelumnya, dengan melihat bahwa adanya kemungkinan khotbah-khotbah, ataupun jejaring organisasi injili yang bekerja lintas denominasi dan organisasi, bukannya tidak mungkin bahwa berbagai orang dengan pemikiran Pentagram Larsen inipun bisa ada di dalam gereja arus utama ataupun organisasi noninjili ini. Dengan demikian, tetap terbuka kemungkinan untuk perihal ini.

${ }^{28}$ Larsen, "Defining and Locating Evangelicalism," 1. 


\section{MERUPA GERAKAN EVANGELIKALISME INDONESIA DALAM KONTEKS}

Tentu ada sedikit pemikiran yang menggantung di sini, apakah maksud dari merupa gerakan injili di Indonesia ini? Stott melihat bahwa empat karakteristik yang diutarakan oleh Bebbington (pada tulisan ini menjadi lima poin) merupakan karakteristik yang tetap menjadi inti dari pergerakan kaum injili walaupun berada di dalam konteks yang berbeda pada setiap zamannya. ${ }^{29}$ Penulis sepaham dengan Stott dan mencoba merefleksikan poin ini pada beberapa peristiwa penting dalam kegerakan kaum injili di dunia.

Misalkan saja, gerakan Puritanisme John Wesley (activism dari Puritan) bertujuan untuk membawa pertobatan (coversionism) pada lingkungan yang sudah melenceng dari ajaran kebenaran Alkitab (cruci-centrism dan biblicism). Gerakan injili di Amerika juga tidak dapat disangkal sebagai suatu gerakan (activism) untuk kontra terhadap gerakan naturalisme dan sekularisasi yang ada di Amerika pada zamannya (biblicism dan cruci-centrism), walaupun gerakan evangelikalisme ini pun akhirnya memisahkan diri dengan gerakan fundamentalisme pada zamannya. Dengan demikian, lima fitur ini pun seharusnya tetap ada di dalam gerakan dari kaum injili di Indonesia.

Lantas, pertanyaannya sekarang, bagaimanakah rupa dari gerakan injili ini di dalam konteks keindonesiaan ini? Sebagai bagian dari "merupa" wujud gerakan injili ini di Indonesia, penulis melihat bahwa ada dua arah gerak dari kaum injili ini, yaitu "gerakan ke luar" dan juga "gerakan ke dalam."

Gerakan ke dalam sejalan dengan moto dari reformasi gereja bahwa sejatinya gereja itu selalu siap untuk berubah (ecclesia semper reformanda est). Gerakan ke dalam ini me-

${ }^{29}$ Stott, Evangelical Truth, 10-11. nyatakan bahwa gerakan evangelikalisme ini juga dapat menyatakan kebenaran Allah di dalam organisasi Kristen yang ada saat ini. Misalkan saja Miroslav Volf menyatakan bahwa ada dua problem gereja saat ini, yaitu kepasifan (idleness) dan ketidakberfungsian (malfunction).${ }^{30}$ Dua problem ini merupakan salah satu wujud kekorupan gereja saat ini dikarenakan gereja sejatinya dipanggil untuk menjadi terang dan garam dunia (Mat. 5:1316), berinteraksi dengan dunia. Pada zamannya pun Yesus melakukan hal yang sama dengan mengritisi korupnya pemerintahan Bait Suci yang tidak berjalan sesuai dengan fungsinya dengan menyatakan "engkau telah membuat rumah Bapa-Ku menjadi sarang penyamun!" (Yoh. 2:13-25). Kebenaran yang sama pun perlu digaungkan oleh gerakan ini mengingat bahwa kerusakan yang sama pun dapat terjadi pada masa kini walau dengan wujud yang berbeda.

Gerakan ke dalam ini ingin membawa penyatuan visi kepada seluruh intradenominasi injili dan juga Protestan (bahkan Kekristenan!) bahwa perpecahan sejatinya adalah kebodohan dan membuat salib Kristus itu menjadi sia-sia (1 Kor. 1:17). Gerakan ke dalam ini juga dapat mencakup bagaimana mengajak kaum Protestan (ekumenis, injili, dan pentakostal) untuk melaksanakan misi Allah di Indonesia. Gerakan ke dalam ini juga mencakup bagaimana mengajak sesama kaum Kristen untuk melaksanakan penginjilan dan menjangkau Indonesia (Yoh. 17:18), yang diterjemahkan baik secara sosial atau pun spiritual. Gerakan injili ini ingin mengajak kepada seluruh orang Kristen untuk mewujudkan doa dari Kristus agar semua orang yang percaya dapat menjadi satu di dalam menjalankan pengutusan-Nya di Indonesia dan di dalam Dia (Yoh. 17:21). Dengan demikian, gerakan ini, jika boleh meminjam perkataan Paulus dalam Galatia 2:20, ingin

${ }^{30}$ Miroslav Volf, A Public Faith: How Followers of Christ Should Serve the Common Good (Brazos Press, 2011). 
menyatakan pada dunia bahwa "namun bukan (hanya) aku (ekumenis, injili atau pentakostal) yang hidup, melainkan Kristus (yang kami percaya) hidup di dalam kami (sebagai kesatuan tubuh Kristus).”

Gerakan ke luar adalah menyangkut bagaimana kontekstualisasi teologi injili pada isuisu yang terjadi di Indonesia saat ini dan terwujud nyata di dalam suatu upaya untuk menerapkan lima karakteristik dari evangelikalisme pada konteks tersebut. Kontekskonteks yang berada di luar dari gereja ini dapat mewujud di dalam problem kemiskinan, politik, pendidikan, kesetaraan gender atau pun konteks lainnya. Pada prinsipnya, gerakan ke luar ini benar-benar menyatakan kembali kepada masyarakat di Indonesia apa artinya suatu aktivitas yang menjunjung Alkitab sebagai otoritas utama sembari kontekstual kepada konteks di Indonesia lewat aktivitas-aktivitas konkret. Baik gerakan ke luar maupun ke dalam inilah yang membuat rupa dari evangelikalisme di Indonesia dapat terlihat. Dinamika dari gerakan ke luar dan ke dalam inilah yang membuat kaum injili di Indonesia dapat merupa wujud gerakan injili di dalam konteks keindonesiaan. Hwa Yung menyatakan demikian di dalam bukunya Mangga atau Pisang?:

Hampir tidak ada keraguan bahwa dalam abad ini, gereja-gereja Kristen di dunia non-Barat telah dan akan menjadi tuan rumah di negerinya sendiri. Gereja Asia akan bertumbuh secara jumlah dan gerakan misi akan berkembang cepatsemoga bukan dalam cara menguasai, melainkan melalui pelayanan yang rendah hati, rekonsiliasi, pengorbanan diri, dan kasih. Hal-hal ini dikerjakan dalam keyakinan bahwa Injil memiliki kuasa untuk mengubah hidup manusia dalam beragam dimensinya untuk menjadi lebih baik. Di sinilah tepatnya gereja-gereja, baik di Timur maupun di Barat, dan Utara, dan Selatan, harus bersekutu bersama untuk mengumandangkan sebuah visi baru tentang keyakinan Paulus, bahwa "Injil adalah kekuatan Allah yang menyelamatkan setiap orang yang percaya" artinya bagi semua gereja dan seluruh dunia. Tentu kita tidak perlu malu karena Injil Kristus memang memiliki jawaban, sekarang dan selamanya. ${ }^{31}$

Penulis sepakat dengan Hwa Yung bahwa panggilan dari seorang Kristen di manapun dia ditempatkan adalah untuk menyatakan Injil yang adalah kekuatan Allah di dalam konteksnya masing-masing. Apa yang Hwa Yung katakan tepat untuk menyatakan maksud penulis di sini. Di dalam konteks merupa wujud gerakan injili di Indonesia inilah penulis melihat bahwa pernyataan Hwa Yung ini dapat memberikan kesimpulan yang sangat baik.

\section{KESIMPULAN}

Tulisan ini masih belum sempurna untuk menjelaskan hal-hal yang berhubungan dengan gerakan injili di Indonesia. Namun, penulis akan mencoba menyimpulkan seluruh refleksinya ini. Gerakan injili adalah gerakan spiritual dan eksperiensial dengan karakteristik teologis: conversionism, biblicism, activism, cruci-centrism, dan pengakuan atas pentingnya peranan Roh Kudus. Gerakan ini dilandaskan pada karakter teologis di dalam konteks keindonesiaan. Implikasinya, merupa wujud gerakan injili di Indonesia dapat diartikan juga sebagai suatu usaha untuk menunjukkan identitas kaum injili pada Indonesia bahwa "Injil adalah kekuatan Allah yang menyelamatkan." Merupa wujud gerakan injili di Indonesia dapat diartikan sebagai suatu usaha untuk menunjukkan pada Indonesia bahwa kaum injili punya jawaban bagi problem di Indonesia, yaitu Kristus yang tersalib itu dan juga

\footnotetext{
${ }^{31}$ Hwa Yung, Mangga atau Pisang?: Sebuah Upaya Pencarian Teologi Kristen Asia yang Autentik, terj. Yohannes Somawiharja, Stephen Suleeman, dan Philip Ayus, ed. ke-2 (Jakarta: Literatur Perkantas, 2017), 354.
} 
kehidupan orang-orang yang meneladaniNya sebagai media kasih Allah bagi Indonesia. Merupa wujud gerakan injili di Indonesia sejatinya merupakan suatu pesan bahwa memang ada Kristus yang tersalib itu bagi Indonesia lewat karya orang-orang yang meneladani-Nya.

Kembali menelusuri data-data yang sudah di -utarakan pada bagian awal dari tulisan ini, penulis melihat bahwa dengan menggunakan model ini, kaum Pentakosta pun sebenarnya dapat dilihat sebagai bagian dari gerakan injili ini. Tidak hanya itu, andaikan gerakan injili ini pun tidak terlihat di dalam kamus tersebut, tetap saja eksistensi dari gerakan injili ini tetap ada dan bahkan bisa jadi dampaknya lebih besar dari yang dapat diperkirakan.

Penulis sadar bahwa masih banyak kekurangan dari tulisan ini. Ada beberapa hal yang perlu dipikirkan lebih mendetail seperti bagaimana wujud kerja sama lintas organisasi yang perlu dilakukan ataupun kekaburan dari makna "gerakan injili" itu sendiri. Tidak hanya itu, penulis sendiri sadar bahwa ada problem bagaimana memaknai perbedaan doktrinal di dalam model ini yang perlu dicermati. Terlepas dari masalah-masalah ini, menurut penulis, model gerakan kaum injili yang seperti ini merupakan model yang ideal. Model ini pun, sebagaimana yang sudah diutarakan pada bagian awal, merupakan suatu investigasi awal. Namun, penulis berharap dari investigasi awal ini, kaum injili di Indonesia dapat mulai memikirkan bagaimana rupa dan wujud "kaum Injili" di Indonesia.

\section{DAFTAR KEPUSTAKAAN}

Aritonang, Jan S. Berbagai Aliran di Dalam dan di Sekitar Gereja. Edisi revisi. Jakarta: Gunung Mulia, 2016.

Aritonang, Jan S., dan Karel Steenbrink. $A$ History of Christianity in Indonesia. Studies in Christian Mission. Leiden, Bos- ton: Brill, 2008.

Barrett, David B., George Thomas Kurian, dan Todd M. Johnson, ed. World Christian Encyclopedia. Ed. ke-2. Oxford: Oxford University Press, 2001.

Castro, Emilio. "Ecumenism and Evangelicalism: Where Are We?" The Ecumenical Review 70, no. 1 (Maret 2018): 5462.

Chan, Simon. "Evangelical Theology in Asian Context." Dalam The Cambridge Companion to Evangelical Theology, diedit oleh Daniel J. Treier dan Timothy Larsen, 225-240. Cambridge: Cambridge University Press, 2007.

Clark, David K. To Know and Love God: Method for Theology. Foundations of Evangelical Theology. Illinois: Crossway, 2003.

Hesselgrave, David J. "Did Cape Town 2010 correct the 'Edinburgh Error'?: A preliminary analysis." Southwestern Journal of Theology 55, no. 1 (2012): 77-89.

Hindmarsh, Bruce. "What Is Evangelicalism?" Christianity Today, Maret 2018. Diakses 1 Juli 2018. https://www.christianitytoday. $\mathrm{com} / \mathrm{ct} / 2018 / \mathrm{march}-w e b-o n l y /$ what-isevangelicalism.html.

Johnson, Todd M, Gina A. Zurlo, Becky Yang Hsu, David B. Barrett, dan George Thomas Kurian. World Christian Encyclopedia. Ed. ke-3. Edinburgh: Edinburgh University Press, 2020.

Larsen, Timothy. "Defining and Locating Evangelicalism." Dalam The Cambridge Companion to Evangelical Theology, diedit oleh Timothy Larsen dan Daniel J. Treier, 1-14. Cambridge: Cambridge University Press, 2007.

Mamahit, Ferry Y. "Apa Hubungan Porong dengan Yerusalem?: Menggagas Suatu Ekoteologi Kristen." Veritas: Jurnal Teologi dan Pelayanan 8, no. 1 (Ap-ril 2007): 1-24, https://doi.org/10.6421veritas.v8i1. 174.

-. "Globalisasi, Gereja Injili dan Transformasi Sosial." Veritas: Jurnal Teologi dan Pelayanan 6, no. 2 (Oktober 
2005): 253-375, https://doi.org/10.36421/ veritas.v6i2.151.

Økland, Øyvind. "Dialogue and Mission in a Globalized World Developments in the World Council of Churches and the Lausanne Movement." Dalam The Lausanne Movement: A Range of Perspectives, 367-382. Regnum Edinburgh Centenary Series 22. Oxford: Regnum Books International, 2014.

Pakpahan, Binsar. "Daftar Anggota Gereja PGI, PGPI, PGLII." binsarspeaks.net, 2013. Diakses Juni 30, 2018. http:// binsarspeaks.net $/ \mathrm{p}=1983$.

Persekutuan Gereja-Gereja dan LembagaLembaga Injili Indonesia. "Sejarah Singkat Persekutuan Injili Indonesia." Diakses 28 April 2020. https://www.pglii. or.id/profil/sejarah.

Siburian, Togardo. "Teologi Kenabian Injili untuk Politis." Stulos 18, no. 1 (Januari 2020): 26-52.

Singgih, Gerith. "Tema Kerukunan Umat Beragama di dalam Diskusi Pakar Agama." Dalam Agama dalam Dialog, disunting oleh Balitbang PGI, 33-54. Jakarta: Gunung Mulia, 1999.

Stott, John. Evangelical Truth: A Personal Plea for Unity, Integrity and Faithfulness. Cumbria: Langham Global Library, 2013.

Sulistio, Thio Christian. "Identitas Kaum Injili dan Perannya dalam Memperkembangkan Teologi." Stulos 18, no. 1 (Januari 2020): 1-25.
Tampubolon, Yohanes Hasiholan. "Refleksi Kepedulian Injili Pada Isu Lingkungan Hidup." Stulos 18, no. 1 (Januari 2020): 53-76.

Vanhoozer, Kevin J., dan Daniel J. Treier. Theology and the Mirror of Scripture: $A$ Mere Evangelical Account. Studies in Christian Doctrine and Scripture. Downers Grove, London: InterVarsity, Apollos, 2016.

Volf, Miroslav. A Public Faith: How Followers of Christ Should Serve the Common Good. Brazos Press, 2011.

Wim, Chandra. "The Chronicles of Evangelicalism: Sebuah Pengantar Historis Terhadap Gerakan Evangelikal." Veritas: Jurnal Teologi dan Pelayanan 12, no. 2 (Oktober 2011): 185-207, https:// doi.org/10.36421/veritas.v12i2.249.

World Evangelical Alliance, "Who We Are?" https://worldea.org/en/who-we-are.

Yosia, Adrianus. "Apakah yang Cape Town Perlu Katakan pada [Kaum Injili di] Indonesia?: Suatu Tinjauan dan Refleksi Terhadap Komitment Cape Town dan Implikasinya pada Kaum Injili di Indonesia." Veritas: Jurnal Teologi dan Pelayanan 16, no. 2 (Desember 2017): 115-134, https://doi.org/10.36421/veritas. v16i2.13

Yung, Hwa. Mangga atau Pisang?: Sebuah Upaya Pencarian Teologi Kristen Asia yang Autentik. Diterjemahkan oleh Yohannes Somawiharja, Stephen Suleeman, dan Philip Ayus. Ed. ke-2. Jakarta: Literatur Perkantas, 2017. 